\title{
MIDLIFE: WHEN THE BODY CHALLENGES TIME
}

\author{
Liliana Singman de Vogelfanger ${ }^{21}$
}

Abstract: This paper considers what occurs during midlife when the certainty-uncertainty tension that inhabits every subject is affected. The body with its drives becomes the messenger who announces the passage of time and life's finitude. Time is challenged by one's own body, triggering a psychic work that will enable the subject to deal with his/her own transience. Based on Freud's writings, the author suggests that one's own body is experienced as an annoying intruder that now bothers, because what is being touched is the idea of his/her own immortality. The emotional state that is generated is one of perplexity and the experience, one of disorientation, accompanied by a feeling of alienation. Each subject's uniqueness will give him/her (or not) the possibility of passing from a feeling of alienation to the reappropriation of that foreign-familiar zone. Due to the psychic impact generated, a change of paradigm is also put forward, if the necessary resources are available. Once the limitations of personal time and the uncertainty of living are recognized, the opening up of what-is-to-come can paradoxically take place, enabling the re-launching of one's own desire.

Keywords: midlife, uncertainty, finitude, body, transience, whatis-to-come.

De un momento a otro puede cambiarle a uno la vida. Es algo sabido que preferimos ignorar... Uno prefiere la engañosa certidumbre con que la vida dispensa mañanas y noches iguales, prefiere creer que la existencia es un manso y predecible rio.

\footnotetext{
${ }^{21}$ The Argentine Psychoanalytic Association; lilianasingman@hotmail.com
} 
Cuando oímos las historias de súbitos sobresaltos nos anclamos en la fe de que a nosotros no nos sucederá lo mismo... En el teje y maneje de la vida el cuerpo es silencioso cómplice. Un día de tantos, sin embargo, nos toca el hombro y nos obliga a mirar su cansancio. Invariablemente la mente se rebela, ella, la alada, la infinita, la que nunca envejece, la que es, se resiste a reconocerse temporal, pasajera. La noticia es inevitable, aceptarla, apropiarse de la fragilidad es el desafio. (Giocconda Belli, El intenso calor de la luna, 2014, p. 71)

[From one moment to the other, life can change. It is a known fact that we prefer to ignore... One prefers the deceptive certainty with which life dispenses mornings and nights that are alike, prefers to believe that existence is a gentle and predictable river. When we hear stories of sudden upheavals, we seek an anchor in the belief that it won't happen to us... In life's give and take, the body is a silent accomplice. On a typical day, however, it taps our shoulder and forces us to look at its exhaustion. Invariably, our mind rebels: winged, infinite, never-aging, the one that always is, the mind resists admitting its temporality, its transience. The news is inevitable; the challenge lies in accepting it, taking charge of our own fragility.]

\section{Introduction: from deceptive certainty to disturbing uncertainty}

Certainty and uncertainty are experiences that sustain and disturb us throughout life. The subject flirts with a deceptive certainty, on the conviction that he is safe from life's misfortunes. Anchoring himself in faith and holding on to beliefs and illusions that provide security, he tries to conjure up uncertainty, thinking that he is in control. Despite lodging in some secret spot the notion that life's misfortunes will not reach him, he cannot fail to observe his own helplessness, peeping through the crevices as a backdrop or invading the whole scene and affecting him.

Rather than juxtapose certainty and uncertainty as opposed polarities, I consider that a necessary tension exists between them that accompanies the development of every subject. The interaction is never stable; it implies a constant negotiation that tries to maintain both terms within certain convenient levels, depending on each singularity. 
There are two currents of thought coexisting in every subject; one in which he recognizes himself as human and therefore flawed and finite, accepting finitude as an integral part of life, (of others); and the other in which he tries to eliminate the presence of death. This is something that he knows, but prefers to ignore, needing at times to believe in the certainty that life is outside time and that one is therefore immortal.

"Time flows in the same manner for all human beings, but each person flows through time in a different way" (Kawabata, 1965, p. 161).

Kawabata's description of time refers to objective time, only accessible through one's subjectivity by the particular way in which we signify ourselves; signification that will be modified throughout one's life. Completing the previous quotation: “... every human being flows differently in time”. This could be understood as the time of analysis, the time of re-signification, where the subject can narrate and think himself in the course of life itself, thus including himself in a temporality that precedes and succeeds him.

There are occasions in life when time appears in other ways, forcing the individual to look at his marks, his future and to cathect a path that has the characteristics that scare him the most: "precariousness, unpredictability, the possibility of inadequacy" (Aulagnier, 1979, p. 27).

\section{Midlife: the uncertainty of living}

In the first years, it is essential for the individual to rely on a stable and secure base that will sustain and reassure him. In order to build one's own future, it is necessary to believe there is a support outside of all questioning that defends us from helplessness and vulnerability. However, the urgency of life, life itself, promotes that the levels of these experiences be modified. What happens when for some reason negotiations come to a halt and the link between certainty and uncertainty is altered?

Various situations present themselves when internal and external occurrences burst in, breaking referents and producing emotions that at first cannot be put into words, producing in the subject a state of astonishment and distress. I will focus on one of these moments, midlife, a stage of the life cycle where time is challenged by one's own body, in turn questioned by time. It is not merely a chronological matter but involves psychic work, triggered when a notification is received that could affect the balance of the certainty/uncertainty tension. Traversing this period will depend on individual subjectivity. 
Midlife, as defined by Montero refers to "... the moment in each individual's life when the person must work out his/her own individual transience starting from certain unequivocal signs, essentially arising from one's drives" (Montero, 2005, p. 68).

Thus, the body with its drives becomes the messenger that brings information to the psyche. On the one hand, this could generate distress, a threat, but on the other it could become a trigger and an impulse, enabling desire in order to invest in one's own project, enabling retroactively to re-signify history. The limit is poignant and will depend on the way each individual crosses it: it could be experienced as a darkened boundary or become a threshold that could enhance the value of life.

The challenge is imperative: taking charge of one's fragility generates an impact in the psyche. The way of dealing with it will depend on one's own subjective experience, set off when making contact with the transience and uncertainty of living. If it were possible to elaborate the intra-psychic processes lodged in each subject, a change of paradigm could also be fostered. Recognizing the constraints of one's personal time would lead, paradoxically, to an opening of what is to come.

\section{The body: "the intruder"}

Even though Freud did not manifestly conceptualize the processes triggered during midlife, significant references in this regard can be found in several of his writings, generally linked to his own personal experience. Concerned about his own death, he was not oblivious of the vicissitudes every individual undergoes at this time.

Guided by certain experiences described by Freud, many of them having taken place during his travels, I will describe certain mechanisms that were set in motion. During his voyage, he was not a mere tourist but made his way like a true traveler, letting himself be carried away by the taste and the climate of each place, each moment; and these left him marks, footprints that interweaved themselves with his life (Sperling, 2014).

Let us begin with his essay on "The Uncanny", published when he was 63 years old, although it was possibly written some years before, when he was overtaken by the superstitious idea that his life was coming to an end. In 1917, he wrote a letter to Ferenczi where he stated: “... at my age, there is nothing strange in realizing the inevitable and gradual personal decline" 
(Jones, 1953, p. 209). In this work, in order to illustrate the effect generated by the double, Freud (1919h) relates the following experience:

"I was sitting alone in my wagon-lit compartment when a more than usually violent jolt of the train swung back the door of the adjoining washingcabinet, and an elderly gentleman in a dressing-gown and a travelling cap came in.... I at once realized to my dismay that the intruder was nothing but my own reflection in the looking-glass on the open door. I can still recollect that I thoroughly disliked his appearance" (Freud, 1919h, p. 248).

The jolt, which seems to have been provoked by an external factor, more than the usually violent movement of the train, compels him to see his own reflected image. The body, which is always an exterior object for the psychic apparatus (Freud, 1923) shakes him and suddenly a door opens and what he perceives, an intruder, displaces and bewilders him, generating a profound vexation. He no longer feels comfortable in his own body; the cabin in which he travels turns into a strange place, provoking a sinister effect that awakens a particular anguish from which he must protect himself. The double changes its sign and passes from being a protector to being "the ominous announcer of death" (Freud, 1919, p. 235). It is a moment of intimate encounter with oneself - "I was sitting alone in my wagon-lit compartment" - when the information of something perceived as external reaches consciousness. Material reality barges in and surprises him. The body, that which is most personal, suddenly appears as an intruder. How can we solve this commotion? (Singman, 2017)

The emotional state, when faced with this impact, is one of perplexity: “... to my dismay..." Freud says. It involves a state of tension between two options that are both presented as valid but unbearable and must be abandoned. Unlike the subject who doubts and does not make up his mind for one or the other, the perplexed individual is certain about both versions but cannot settle himself comfortably in this contradiction, a situation that promotes movement. In some cases, depending on individual subjectivity, the perplexity could result in accepting the coexistence of antithetic visions, generating a different positioning that could allow the acceptance of life's paradoxes.

After that first anguished reaction, the experience is one of rejection for not wanting to accept the reflected image; but the body insists. 


\section{The drive increase}

That which is insistent and inescapable is the drive increase that knocks from within until it can be heard and signified. The drive, a border concept between the somatic and the emotional, is the yardstick imposed on the emotional by its link with the physical. Freud describes two moments in life when, due to the metabolic processes initiated by puberty and climacterics (feminine and masculine), a drive reinforcement takes place that will promote certain psychic experiences; these are the expression of what happens to the mind as an answer to the somatic question.

Freud refers to this phenomenon in several of his texts. In his essay "Leonardo da Vinci and a memory of his childhood" (1919c), he states: "At the summit of his life, when he was in his early fifties - at a time when in women the sexual characters have already undergone involution and when in men the libido not infrequently makes a further energetic advance - a new transformation came over him" (Freud, 1919c, p. 134). Several years later, in "Analysis Terminable and Interminable" (Freud, 1937c), he observes: "Twice in the course of the development of the individual certain instincts are powerfully reinforced: at puberty and at the menopause in women.... When his instincts were not so strong, he succeeded in taming them, but when they were reinforced, he can no longer do so" (Freud, 1937c, p. 226).

These drive reinforcements, libidinal and aggressive, are a working demand for the psychic in both stages of life and modify continuity, giving rise to psychic work in adolescence and midlife. (Montero et al., 2012) The way in which this is solved will depend on the personal history and the available structure, and various outcomes will present themselves, ranging from stagnation to elaboration.

The emergence of forces, which at first are impossible to understand, leaves the subject disconcerted, but also kick-starts the psychic apparatus. For this reason, ideas of growth, movement and strength are always summoned around the word Trieb (Scarfone, 2005).

\section{Being 'at a loss'}

Perplexity, the emotional state that ensues as a reaction to what barges in during this stage, highlights the feeling of disorientation or, in Freud's words, of being at a loss. The possibility of placing oneself in time and space is lessened. Living goes hand in hand with being able to hold on to certain 
referents that help to get one's bearings, coordinates that allow an individual to position himself and provide a point of departure and a destination.

When Freud was 59 years old, the themes of war and death imposed themselves on his personal life. With the advent of the First World War and in an attempt to provide an answer to the impact this phenomenon provoked, in 1915 he gave a lecture entitled: "Death and Us" and wrote two essays which later became: "Thoughts for The Times On War And Death: The disillusionment of the war and Our attitude towards death" (Freud, 1915b). In these writings, Freud reflected on the attitude human beings adopt with regard to death and how war alters this relationship.

He argues that the focal point whose modification will affect an individual the most is the relationship he establishes with death. The latter is usually considered as something unusual, distant; the subject even comes to doubt his own death. Nevertheless, in war scenarios, death can no longer be denied. The change regarding one's attitude towards death, a change that is sudden, since the topic is not chosen but imposes itself, provokes this disorientation: "We ourselves are at a loss as to the significance of the impressions which press in upon us" (Freud, 1915b, p. 275).

The irruption of the death theme may come from exterior reality, as a war scenario, or from the inner self. I support Freud's view regarding the impossibility of representing one's own death despite the fact that the psyche always makes efforts to find some way of representation.

I would like to make a parallel between both irruptions, but not without taking into consideration the different effects of what a social catastrophe can imply, often leaving an irreparable psychic damage, from a drive emergency that kick-starts a possible elaboration with a time that is very different to the time of war.

In the process set off by war, the unconscious relationship with death is exposed. When Freud states that death can no longer be overlooked, he is suggesting that what is disrupted is the mechanism with which each individual used to function, partly trying: "to eliminate it from life... we tried to hush it up" (Freud, 1915b, p. 289).

During midlife, the stage of life when the drive, due to its connection with body changes, is incremented, the theme of finitude appears. Something which was destined to remain hidden comes to light, and the prehistoric man, who immutably survives in the unconscious believing himself immortal, feels under threat (Freud, 1915). 
The individual may feel disoriented and perplexed, since the balance that allowed him to find his way in life is broken. The invisible becomes visible, promoting a processing effort of vulnerability and helplessness where the certainty and secret belief in one's immortality is shaken, with the narcissistic offence this implies. This impact, which comes from the body drive, generates confusion and promotes the start-up of an intra-psychic taming work - the search for a new orient that will allow him to reposition himself (Singman, 2012).

\section{Derealization: "what I see there is not real"}

Together with disorientation, a pathognomonic state of mind during this stage of life is the experience of derealization or alienation, which awakens the contact with something that is experienced as alien, as in something that is disturbing and that the subject feels is not real and does not belong to him. The word derealization means an alteration in perception leading to the feeling that the reality of the world has been changed or lost (Webster's, 1996).

Once again alluding to a personal experience, Freud provides an example of his own alienating experience in a letter he writes to Romain Rolland on the occasion of his friend's birthday (Freud, 1936a) Even though in this instance there is a clear reference to the feeling of guilt for having surpassed his own father, I was surprised to discover a subtext referring to a formulation of the work carried out during midlife, when the subject acknowledges the passage of time.

Freud chooses this episode to honor his friend, describing what he experienced during a trip when he was forty-eight years old. Even though he does not directly express it, the anecdote is full of references that evince how the course of his life presented itself differently. To begin with, he refers to a trip, metaphor of life, and concludes his letter saying: "I can travel no more". This remembrance had been described ten years before in his essay: "The Future of an Illusion" (Freud, 1927c), when he had questioned the strength that supports man's need to believe in a protecting god, answering that such a strength reflects humanity's helplessness.

When he was eighty years old, affected by his age, he remembered a trip to Athens undertaken during a stage of his life, "I was already a man of mature years" (Freud, 1927c, p. 25). It is a moment of awareness of the voyage undertaken and what still remains of it, a sense of total uncertainty, but with the certainty it will come to an end. With hindsight, however, he 
believes he can now throw some light on the 'phenomenon' that occurred to him so many years ago, and that he could not understand at the time.

Before commencing with the tale of his journey, however, he makes the following request: "... I shall have, of course, to ask you to give more attention to some events in my private life than they would otherwise deserve" (Freud, 1936a, p. 239).

But to what, exactly, would it be important to give more attention? This phrase is a new confirmation for the reading of the subtext present in this letter.

Continuing with the allusions to the chronological, he writes: "My brother is ten years younger than I am; so he is the same age as you-a coincidence which has only now occurred to me-". Furthermore, in the Acropolis, "I was then 48 years old. I did not ask my younger brother whether he felt anything of the same sort." (Freud, 1936a, p. 243)

He commences by writing that for work reasons pertaining to his brother, they had to shorten their trip. He describes different emotions and thoughts that arise throughout the journey: "remarkably depressed spirits", "discontented and irresolute frame of mind", "gloomy state", "sadness", "incredulity". He describes how they walk around the city, until the shipping company opens and they finally book their tickets, "without bothering in the least." (Freud, 1936a, p. 240)

In Athens he has a thought that surprises him: "So all this really does exist..." (Freud 1936a, p. 241). On subsequent analysis, he realizes that he was hiding an unconscious thought: “... what I see there is not real." $\mathrm{He}$ describes this phenomenon as a split of the personality, where the person who had the thought separated himself from the person who perceived it, surprising them both. One person behaved as if, under an unquestioning observation, he was forced to "believe" in something whose because he had never known that real existence could be doubted; in this case, [the existence of] the Acropolis.

He conceptualizes this feeling of derealization as a complex process, a failed operation of abnormal construction which, just as with dreams, also occurs to normal persons. If the denial mechanism had been successful "What I see there is not real", the derealization phenomenon experimented by Freud would not have existed (Marucco, 2000). These "determinations to exclude something of ourselves" can take place in two ways: if what is experienced as something coming from outside is a fragment of reality, we would be talking about derealization; if it is a fragment of the ego, it would be “depersonalization”. Both mechanisms co-belong. (Freud, 1936a) 
Freud describes various modes of behaviour that the ego can have when faced with something painful and unbearable ranging from admission, reflection, judgment and action according to ends, to more or less pathological defences. An extreme case is exemplified by the manner in which King Boabdil, the last Moorish king of Granada, reacted when his kingdom fell. Refusing to take the news for certain, he decided to treat it as a non arrivé by burning the letters and having the messenger killed. "The versus runs: Cartas le fueron venidas de que Alhama era ganada: las cartas hecho en el fuego, y al mensajero matara." (Freud, 1936a, p. 246)

If a reality exists that a part of the personality considered uncertain up to that moment, it is the reality of our own finitude; part of it is believable and the other part considered alien, belonging to others. Faced with the news that the trip will be shortened, a discomfort sets in that produces astonishment and cannot at first be understood. It is believed that the motive is external, outside the subject. In Freud's narrative, the responsibility for the discomfort generated by the change of plans is placed on his brother. The subject walks around until, at a certain moment, it becomes possible to elaborate this feeling that "disturbs the use of reason and of the senses", and a ticket could be purchased to continue the voyage.

The letters arrive announcing the fall of the kingdom. But if the subject can receive the letters without burning them and recognize them as his own, a psychic change could be generated that would allow him not only to continue with the voyage but to re-launch it.

\section{Change of paradigm}

In my view, the impact produced by the acknowledgment of life's transience and uncertainty could provoke a psychic reorganization. The life cycle proposes a mutation of the paradigm, of the Weltanschauung, which served the subject as a guide. It is a moment of a certain confusion, anxiety and perplexity because the anchor point is touched. It deprives us of our orientation in life, bringing up existential questions that define the human condition: Where do I stand? Where am I going?

It is not a topic that we choose to think about; the subject is imposed with the psychic task of recognizing the passage of time: that finitude is no longer a life contingency. It is a time which is different from succession; it is the time of occurrence, the coming of the unprecedented (as Benjamin called it) where something explodes, re-signifying itself (Sperling, 2014). A cut of 
time within time that would kick-start a process of resignification of past and future. The pillar that provided certainty is shaken and this could generate a great mobilization in the psyche, producing in certain cases a repositioning of life, a change of perspective.

Paradigm, a term that comes from the Greek Word: paradeigma meaning model, example, standard, the way in which the world is seen and interpreted. Thomas Kuhn applied the concept to the scientific world, considering that paradigms are scientific and universally recognized developments that, after a certain time, provide models of problems and solutions. It is not simply a current theory but a whole worldview within which it exists.

The change occurs when scientists find anomalies that cannot be explained with the model accepted up to that moment. Sometimes, it involves faults that are discarded as acceptable error levels and not taken into consideration. However, when significant anomalies accumulate against the prevailing paradigm, scientific discipline falls into a state of crisis. It is a question of passing from the old to the new and not simply of correcting or simply adding to what was previously known.

An intellectual battle ensues between those who resist and those who welcome the change until finally a new paradigm is created where a way of thinking is altered and certain phenomena are described. The new model emerges due to the discovery of different ways of seeing and doing things (Kuhn, 1987).

Even though referring to different scenarios, I take the liberty of incorporating Kuhn's developments in order to extend them to my theorization. For this reason, I suggest that these insights could represent in part what occurs at the intra-psychic level, when the subject makes contact with life's transience and reconsiders the current paradigm. The psychic reorganization that is generated could imply in some cases a forward-looking change, since the certainties believed by the subject up to then and in which he took refuge stop functioning. In other cases, conversely, it will be the declamation of a movement that could not be carried out, but the intent of change always exists.

It is a liminal moment, of passage, because it implies standing at the threshold of a model that falls and one that has not yet been built. When the Weltanschauung is questioned, that which to a certain extent helped the subject to feel secure in life (Freud, 1933), the need to negotiate in a different way with one's own uncertainty arises, trying to integrate those truths that up to this moment seemed uncertain. From believing in certainty to coping with uncertainty. The subject finds himself in a transit state until he is able, 
in some cases, to accept that precisely this transit state is the one required to integrate in the new paradigm.

\section{"The death of God"}

What occurs somehow to each individual, quoting Nietzsche, is "the death of God" (Nietzsche, 1882 p. 291), from which the subject never quite recovers. And which impels him to come face to face with the abyss and accept that life is played on a board where not everything is defined and assured. It is important to note that the Nietzschean syntagm, the death of God, does not merely allude to a religious sense but rather to the fall of what god represents to each individual; the guarantee, the base that provided certitude, in part, of the future itself. That illusion of a divine plan, of the totalizing tale that guided life and allowed one to feel safe. What appears now is what is, each subject's desire and possibilities, where the rule imposed by life's game is the legality of finite time (Sperling, 2014).

Or, in Freud's words (in a clear reference to his reading of Nietzsche): "The mask has fallen; it leads to a denial of God" (Freud, 1927c, p. 36) and therefore if individuals are aware of being in possession of larger forces, they have also realized life's dangers: "They ... will find themselves in a difficult situation. They will have to admit to themselves the full extent of their helplessness and their insignificance in the machinery of the universe; they can no longer be the centre of creation, no longer the object of tender care on the part of a beneficent Providence" (Freud, 1927c, p. 49). It is worth noting that each time Freud refers to these experiences, he uses a terminology linked to religion: faith, belief, confession etc.

What is being moved is the secretly believed certainty, the illusion of the totality and coherence in which uncertainty found solace. The individual was partly aware that it was about an illusion and another part of him needed to believe in its absolute dominion. "The Ego does not defend illusions; it defends "its own truths" with everything that could force it to admit that they are no more than illusions" (Aulagnier, 1979 p. 240).

Making contact with the uncertainty of living generates anxiety, since it connects with that vulnerability that was once experienced, when one had to depend on external help in order to survive. When, at certain moments, it is inferred that one is helpless and unprotected, the defence against such helplessness will be given by the characteristics that reaction had in childhood, with the longing of being protected from the consequences of human 164 
impotence. (Freud, 1927c) The individual is now faced with the difficult task of integrating it to his own life, admitting the link with his own impotence, his finitude. It involves making that silent knowledge a bit more audible and thus being able to cope with it differently, always with a certain amount of denial: we never completely find out because, otherwise, it would be intolerable.

"Because of death, because of the fear of dying, all knowledge commences" (Rosenzweig, 1997 p. 43).

Awareness of the boundary sets in motion the desire to know - a search for answers, as an attempt to mitigate the impact, looking for a way to give sense to that which overwhelms the subject, who does not know where to place himself. A tension is generated between being able to tolerate "knowing that one does not know", one of the less natural stances of thought, late acquisition and always fragile (Aulagnier, 1979 p. 78) and the illusion of being able to find a more mythical explanation. There will always be a place from which protection will be requested before "the painful riddle of death, against which no medicine has yet been found, nor probably will be" (Freud, 1927c, p. 16).

The subject will fluctuate from admitting the need to find an explanation that offers the comfort that a father exists, a god that takes care of and decides for them, with the task of reconciling “... men to the cruelty of Fate, particularly as it is shown in death, ..." (Freud, 1927c, p. 18), and being able to tolerate that there are many situations which have no answer. As Freud puts it, those who manage to accommodate themselves to the minute role they occupy in the universe could be considered "irreligious in the truest sense of the word." (Freud, 1927c, p. 32)

Could we therefore conceive midlife as a stage that would provide the individual with the opportunity of becoming more irreligious and that this position would in turn promote a search that could set desire in motion? The opposite could also occur.

Just as in the scientific field, intra-psychic battles take place between those who follow the old paradigm and those who are open to the new. These resistances take some time, a time that is neither instantaneous nor tranquil.

\section{Appropriating the finite body}

The intruder, as I previously described, is the body. "The mark of being mortal is always executed in one's own flesh" (Alizade, 2012, p. 41). At first, it is about a knowledge that is physical and not intellectual; the body exposes the passage of time, taking note of its finitude. Confronted 
with the news, the ego tries to defend itself because, as described in the introductory quotation to this work: "Invariably, our mind rebels: winged, infinite, never-aging, the one that always is, the mind resists its temporality, its transience" (Belli, 2014, p. 71).

Western culture sinks its roots in Platonic thought, marked by the dualism body/soul, where one element is more important than the other. The body is the representative of finite temporality and therefore experienced as flawed and imperfect. The soul, in contrast, is perfect and eternal. The only thing that dies is the physical wrapping; the soul remains sheltered.

The new paradigm suggests a different logic that would allow the transition from a dualistic thought, confronting body and soul, the disposable from the eternal, to a logic where difference can have its place; a difference not pierced by a binary logic. Not only is one not better than the other but both are akin to one another. "The psychic and the somatic are two aspects of only one biopsychic being. Between them there is caesura but not rupture" (Scarfone, 2005, p. 42).

That same body, property which the individual regarded as being its sole owner and master, a source of pleasure, could also become a source of suffering. Despite the rejection it produces, especially when the individual discovers that the body is what condemns him to his death; and that it is an object that cannot be lost, one cannot separate oneself from it (Aulagnier, 1979). The body will be loved or hated but can never be regarded with indifference.

How can one pass from the alienation and disavowal generated by one's body to a re-appropriation?

How can the intruder inside ourselves be accommodated?

How can that flawed body whose changes no longer cease to silence the passage of time and the uncertainty of living be tolerated?

The development work, if the resources to initiate it are available, requires an absolutely personal time that will entail the implementation of various processes. Firstly, the impact, the confusion, the disorientation, the feeling that this cannot be true. A work of mourning commences, for that which no longer is and for what never existed, and the task imposed on the subject is to re-lodge himself. This implies the re-signification of the maternal function that allowed him to feel looked at and supported and which also bestowed the difference. A maternal discourse that cathectized the pleasure body and the suffering body during the first stages, permitting that the rejection of suffering generated by one's body go hand in hand with the cathectization 166 
of that same body (Aulagnier, 1979). That encounter or missed encounter is re-edited, giving the possibility of writing or registering for the first time a different encounter (Montero et. al., 2012).

At this moment in life, the body appears to the subject firstly as an external picture that does not belong to him, and as an observer he asks: who is this stranger? After that, he begins to be part of that scene and the subject himself will be the one supporting and containing his own body with his drives, enabling him to reside within it and preserve the certainty of inhabiting one same and unique body, regardless of variations.

The re-signification will be the return to a same place, but establishing a difference, recognizing the subjective continuity by means of the changes. One's own home is not the same but it will continue to be my home. The cohabitation in and with it will bring new experiences vis-à-vis the unknownknown; experiences that will kick-start a time of appropriation and creation so that the subject may be able to find himself once again in the cabin that lodges him and allows him to take refuge and relax alone or with others, but from that most profound element that constitutes him. This will enable the new encounter with the body to be less ominous, so that he can feel that he is returning home once again, to a house that includes the limits and uncertainty of living as well as a new perspective of time; a house that will no longer be firm and secure but will nevertheless confront him with the changes that will unfold throughout life, securing the permanence of a stable base that will permit the subject to sustain that the title deed of the property continues to be in his name (Aulagnier, 1986).

At this point, moments of acceptance will fluctuate with moments of rejection, since what is occurring does not happen only once but continues to occur, provoking effects. Even though nothing will be quite the same as the first impact, and the subject will not be caught so unawares, agitations and a certain degree of confusion will continue to happen. In this new dialogue with the mirror, the subject recognizes and denies himself, living simultaneously with a foreign/familiar zone that inhabits him. The body is in permanent change but, in contrast with other moments in life, it now bothers him because what is being touched is the idea of immortality.

Another negotiating scenario in the battle that is played out is with the ideal Ego, a state of perfection reached, a state of being and not of what is to come, which functions like an eternal present, denying the passage of time (Hanly, 1983). The thorniest point of the narcissistic system, the immortality of the ego, is besieged at this moment of life by the reality that is imposed, 
endangering its refuge and the refuge of the past generation that placed in its son its own hopes of immortality, enthroning the boy in the place of "his majesty the baby" (Freud, 1914c). It is a moment which gives full rain once again to the assassination of the marvellous boy, murder that never occurs in one go; the longing of returning to being that immortal child is always reawakened (Leclaire, 1975). Unloading such hopes could become liberation for the individual, so that his own desire could lead the way, enabling him to invest in possible ideals that take singularity more into account (Singman, 2008).

\section{From a closed time to opening up what-is-to-come}

I consider that during midlife, as at other moments in life, the opportunity arises to question the more mythical explanations that all individuals continue to hold on to as resting places, when the gods decide their destinies, providing the answers. Once questioning is allowed, those thoughts would affect the subject once again, re-launched with new meaning. In this way, they could pass from a closed time, when everything was written, to an opening of what is to come. Transforming "fate", that power that determines the result of events before these occur, into a "destiny", more linked to action and the "interior language" of each subject. Bollas (1989), when referring to destiny, gives it a different meaning, describing it as a life potential related to "the true self". A movement open to the future and not a mere oracular projection. "The sense of fate is a feeling of hopelessness of not being able to influence the course of one's life. On the other hand, a sense of destiny is a different state, whenever the person feels he advances in a progression of personality that gives him the sensation of steering his own course" (Bollas, 1989, p. 56).

The psychic mobilization that takes place during this period modifies the notion regarding the perception of one's own temporality. When we recognize the transience to which we are exposed as humans, the passage of time becomes more present, the voyage of life, a life that is not eternal. From the moment the limit is acknowledged, the limit of time, today becomes that which is most precious. It is the end of postponement, a mechanism that seemed destined to try to deny finitude. A different dialogue with past, present and future commences, as a crossing of different times: chronological time, today's time, the time of uncertainty and the time of transmission, among others.

“...We are all enrolled in a genealogy of subjects that do not ignore their mortality ... it is precisely that which differentiates what is human from 
what is animal: a knowledge about death and the genealogy that dictates the need of assuring a minimum of continuity" (Hassoun, 1996, p. 15).

Even though this is a process that takes place forever, awareness of one's mortality marks the need of transmission (Singman, 2006). When orientation in time and space re-signify themselves, the following questions ensue: from where and towards where, with time accompanying and discriminating generational places, a before and an after. The way in which each subject narrates himself will always include an answer regarding one's origin, a selfrecognition of being an heir, the link with past generations and, in turn, a need of being the transmitter of the following generation. The succession of generations creates time; all generations have a debt with those who have preceded them and "with those that will follow, in an infinite chain, only way of infinitude to which the speaking being has access to." (Sperling, 2008, p. 9)

I ask myself, together with Piera Aulagnier (1979): "What pleasure premium allows the Ego to cathectise a temporal flow that leads it towards death?" (Aulagnier, 1979, p. 30).

The ability to make contact with the idea of one's own finitude goes hand in hand with assuring oneself of "a small piece of immortality". The Ego cannot conceive that this human earth will remain indifferent to its disappearance ... it needs to believe that its existence has meaning." (Aulagnier, 1979, p. 233) The narcissistic prize that will allow it, at certain moments of life, to maintain the interrogation regarding one's death will be to believe that something of itself will remain: "a mark, a simple touch, a scratch." Only then, "The Ego, unable to do anything else, is willing to accept death, and to renounce believing in heaven ..." (Aulagnier, 1979, p. 244)

Those marks one wishes will remain on this earth, will be the consequence of acts carried out today. The future will be the effect of what each subject does during his life, realizing that the moment is unique:

"As honest smallholders on this earth they will know how to cultivate their plot in such a way that it supports them. By withdrawing their expectations from the other world and concentrating all their liberated energies into their life on earth, they will probably succeed in achieving a state of things in which life will become tolerable for everyone ..." (Freud, 1927c, p. 50) 


\section{Paradox of life}

"If you want to endure life, prepare yourself for death." (Freud, 1915b, p. 300)

Freud develops a significant paradox when he states that life will be enriched if we manage to integrate death. In his essay "On Transience" (1916a), he writes:

"Transience value is scarcity value in time... The beauty of the human form and face vanish for ever in the course of our own lives, but their evanescence only lends them a fresh charm. A flower that blossoms only for a single night does not seem to us on that account less lovely" (Freud, 1916a, pp. 305-306).

During midlife, history resignifies itself; it is a time when a re-update of the ideal ego/ ego ideal, takes place. This gives the possibility of downplaying failures and successes, enabling us to admit that flaws and limits are inherent to the human condition and that without the capacity for frustration time would come to a halt, history resignifies itself. A new version of history may be written, permitting previous chapters to be read and allowing for a new temporality of the uncertainty of living. Passing from the closed temporality of the mythical stage to an open temporality with new questions will become possible. This will be the way that will enable more life; this is the challenge the subject will confront when he takes ownership of his own transience.

Paradox of life that when the fact that time is limited is admitted and frustration of the not possible tolerated, time is gained. It is the opportunity offered by the life cycle to promote, deepen and continue individual development as well as an encounter with authenticity (Montero, 2015). It is a time when the possibility of re-launching desire in an open and inconclusive time becomes possible. This occurs because leaving certainty behind and renouncing to assurances, challenging the destiny marked by the gods, the possibility to question is enabled, permitting the subject to find his own interpretations, the ones that he alone can create.

The interpretation is not the disclosure of an only truth but a process that builds meaning in the multiple readings that have not been previously set. Never has everything been said and there is not just one way of saying. Thus, the subject can set in motion his own text, his own desire and the possibility of authorizing himself, enabling him to be: “... a responsible author and not a passive spectator of his own destiny" (Kancyper, 1985, p. 538). For this reason, I cannot put a name to the new paradigm because an only way of 170 
traversing it does not exist; each individual will discover his own way of naming it.

If traversing this path is achieved, it becomes an opportunity of resigning, of re-affirming a new contract, with clauses that could permit each subject to deal with and become responsible for himself. This is a nonlinear process, which takes place throughout life, with advances, setbacks and resignifications. The subject knows that death is a part; he does not know when or how but is aware that it travels with him in his ship. If the unbearable is admitted, mortality of the ego, life will become more liveable, since it will not only be about navigating, but also about living. As Freud points out: "Life is impoverished, it loses in interest, when the highest stake in the game of living, life itself, may not be risked" (Freud, 1915b, p. 290).

The degree of toleration will depend on the structure of each individual. If the experience of uncertainty is a threat of disintegration for the psyche, he will resort to some guarantee that will calm the anguish in the face of helplessness. He will jump from one certainty to another in order to avoid falling into the abyss; only with its help will he be able to withstand life.

The possibility of elaborating the processes set in motion and of lodging that which one wanted to exclude from oneself will allow the individual to appropriate himself of a changing and finite body, challenging time and enriching life. A new balance appears, always transitory in the certainty/ uncertainty tension that accompanies all that is to come. Recognizing the uncertainty of living and transience as traveling companions could become one's personal search engine. A search that will no longer involve closed questions but open ones, accepting that a single answer does not exist and that the void is impossible to fill. Void which, albeit often with the nostalgia of wanting to cover it once again, will not be replaced with an absolute truth but rather with the need of momentarily creating something that may calm it, being able to feel that there is space left for the rest of one's life, in order to create one's own future in the best possible manner: running the risk of living.

\section{Conclusions}

In this work I have considered the tension certainty/uncertainty which in my view is lodged in every subject. On the basis of some of Freud's writings, I have asked myself what happens during midlife, a moment in the life cycle when time is questioned by one's own body. 
The body becomes a stranger, shaking the balance of the alluded tension. It is paradoxical that the most intimate part of ourselves suddenly appears as an intruder, generating an uncanny effect.

It would seem that this intrusion is related to a drive increase which is the psychic result of metabolic issues that characterize this stage of life, promoting certain psychic experiences. It is essential to realize that the way of dealing with it will assume different facets, according to each subjectivity.

When faced with this impact, the emotional state is one of perplexity and the experience one of disorientation. This will set in motion a psychic 'taming' work that will allow the subject to reposition himself.

Another pathognomonic feeling is the alienation awakened by the contact with something that is experienced as foreign and is consequently disturbing. If a reality exists that a part of the personality considers uncertain, it is the reality of one's finitude. The coordinates of reality tighten once again, requiring a new adaptation.

The task of the subject is to think about his own temporality, also being able to project a future time. At this moment of life, time makes itself present in a different way, forcing him to look at his marks, his future. A new dialogue commences with time; when the limitations of personal time are recognized, an opening of what-is-to-come could paradoxically occur.

The singularity of each individual will provide, or not, the possibility of passing from an alienating and rejecting effect generated by one's own body to a re-appropriation that will allow him to lodge the intruder within. In some cases, the new encounter with that foreign/familiar area that lies within can be made possible, making it less ominous. This can result in a feeling of returning home, a home that includes the limit and the uncertainty of living and a new perspective of time.

When the illusion of totality and coherence that gave solace to uncertainty is shaken, "the mask falls", with the wound to narcissism that this provokes. "The death of god" alludes to the collapse of the guarantee, that which gave certainty, in part, to one's future. A part of the subject knew that it was about an illusion, but another part needed to believe in its absolute dominance.

The psychic impact generated could provoke a psychic reorganization, a change of paradigm. In some cases, we shall witness an authentic reorientation that implies a prospective change and in others a declamation of something that cannot be carried out. 
When the subject receives the messenger "without burning the letters", recognizing that the voyage is shortened and that the path ahead is absolutely uncertain, but certain of its end, he is able not only to continue the trip but to re-launch it. From then on, taking charge of the finite body will become possible, enabling an aperture. A paradox of life implying that once the limitations of personal time are admitted more time will be gained.

Being able to appropriate oneself of fragility challenges time and enriches life. Desire is revived and one's own idiom is set in motion. For this reason, it is not possible to name the new paradigm; each one will find his own way of traversing and naming it, since what-is-to-come will be the result of what each individual does with his own life.

\section{REFERENCES}

ALIZADE, M. (2012). Clínica con la muerte [Clinic with Death]. Ediciones Biebel, Buenos Aires.

AUlAGNIER, P. (1979). Los destinos del placer [Destinies of Pleasure]. Paidós, Buenos Aires, 1994.

(1986). Un intérprete en búsqueda de sentido [An interpreter in search of meaning]. Siglo Veintiuno Editores, Madrid, 1994.

BELLI, G. (2014). El intenso calor de la luna [The intense heat of the moon]. Grupo Editorial Planeta, Buenos Aires.

BOLlAS, Ch. (1989). Fuerzas del destino [Forces of Destiny]. Amorrortu Editores, Buenos Aires.

FREUD, S. (1910c). Leonardo da Vinci and A Memory of His Childhood. SE XI. Hogarth Press, London, pp. 59-137.

FREUD, S. (1914). On Narcissism: An Introduction. SE IV. Hogarth Press, London, pp. 67-100.

FREUD, S. (1915). Thoughts for The Times On War And Death. SE $X I V$. Hogarth Press, London, pp. 273-300.

FREUD, S. (1916a [1915]). On Transience. SE XIV. Hogarth Press, London, pp. 303-308. 
FREUD, S. (1916b), Nosotros y la muerte [Death and Us]. Revista de Psicoanálisis, Asociación Psicoanalítica Argentina. Vol. LXVII(4):543-554, 2010.

FREUD, S. (1919). The 'Uncanny'. SE XVII. Hogarth Press, London. pp. 217-256.

FREUD, S. (1923). The Ego and the Id. SE XIX. Hogarth Press, London. pp. 1-66.

FREUD, S. (1927). The Future of an Illusion. SE XXI. Hogarth Press, London, pp. 1-56.

FREUD, S. (1933 [1932]). New Introductory Lectures on PsychoAnalysis. Lecture XXXV. The question of a weltanschauung. SE XXII. Hogarth Press, London, pp. 146-168.

FREUD, S. (1936). A Disturbance of Memory on the Acropolis. An open letter to Romain Rolland on the occasion of his seventieth birthday. $S E$ XXII. Hogarth Press, London, pp. 239-250.

FREUD, S. (1937). Analysis Terminable and Interminable. SE XXIII. Hogarth Press, London, pp. 209-254.

HANLY, C.M.T. (1983). El ideal del yo y el yo ideal [Ego Ideal and Ideal Ego]. Revista de Psicoanálisis, Asociación Psicoanalítica Argentina. Vol. XI:191-203.

HASSOUN, J. (1996). Los contrabandistas de la memoria [The memory smugglers]. Ediciones de la Flor, Buenos Aires.

JONES, E. (1953). Vida y obra de Sigmund Freud [Life and work of Sigmund Freud]. Ediciones Hormé, Buenos Aires, 1996.

KANCYPER, L. (1985). Adolescencia y a posteriori [Adolescence and a-posteriori]. Revista de Psicoanálisis. Asociación Psicoanalítica Argentina, Vol. XLII(03):535-543.

KAWABATA Y. (1965). Lo bello y lo triste [Beauty and Sadness]. Emecé Editores, Buenos Aires.

KUHN, T. (1987). Que son las revoluciones cientificas y otros ensayos [What are scientific revolutions and other essays]. Paidós, Buenos Aires. 
LECLAIRE, S. (1975). Matan a un niño [A child is being killed]. Amorrortu Editores, Buenos Aires.

MARUCCO, N. (2000). Respuestas a los comentarios sobre „El placer en la fantasía y en la realidad" [Answers to the comments on "Pleasure in fantasy and reality"]. Revista de Psicoanálisis. Asociación Psicoanalítica Argentina. Vol. LVII(01):7-17.

MONTERO, G. (2005). La travesía por la mitad de la vida [Traversing midlife]. Homo Sapiens Ediciones, Buenos Aires.

MONTERO, G. CIANCIO DE MONTERO, A., SINGMAN DE VOGELFANGER, L. (editors) (2013). Updating midlife: Psychoanalytic Perspectives. Karnac Books, London.

MONTERO, G. (2015) Psicoanálisis de la madurescencia. Definición, metapsicología y clínica. [Psychoanalysis of Maturescence: Definition, Metapsychology and Clinical Practice]. The International Journal of Psychoanalysis. (en español), Vol. 1(6):1753-1781.

MONTERO \& col. (2012). Cuando los perros no están dormidos. Algunas conceptualizaciones acerca de la vida pulsional en la mediana edad. [When the dogs are not asleep. Some conceptualizations regarding the life drive in midlife]. Fundación Travesía, Buenos Aires.

NIETZSCHE, F. (1882). La gaya ciencia [The gay science]. Editorial EDAE, Madrid, 2011.

ROSENZWEIG, F. (1997). La estrella de la redención [Star of redemption]. Ediciones Sigueme S.A.U., Salamanca.

SCARFONE, D. (2005). Las pulsiones [Drives]. Ediciones Nueva Visión, Buenos Aires.

SINGMAN DE VOGELFANGER, L. (2006). La función adulta en la confrontación generacional. De la claudicación a la continuidad. [The adult function in the generational confrontation. From claudication to continuity]. A.P.S.A. Capítulo de Medicina Psicosocial. La escucha psicoanalítica en Psiquiatría. Vol. V:83-87.

SINGMAN DE VOGELFANGER, L.(2008). Vicisitudes del proceso de transmisión-apropiación [Vicissitudes of the transmission-appropriation 
process]. Paper presented at Asociación Psicoanalítica Argentina, Buenos Aires.

SINGMAN DE VOGELFANGER, L. (2012). La desorientación en la mediana edad [Disorientation in midlife]. Fundación Travesía, Buenos Aires.

SINGMAN DE VOGELFANGER, L.(2017). La intimidad familiar y la intimidad ominosa en la mediana edad. ¿Cómo alojar al intruso que hay en $m i$ ? [Family intimacy and the ominous intimacy in midlife. How do I lodge the intruder within?]. Panel IPA at 50Th Congress, Intimacy, Buenos Aires.

SPERLING, D. (2008). Contra la pureza [Against purity]. Docta Revista de Psicoanálisis. Año 6, N4:141-148.

SPERLING, D. (2014). Filosofía para armar. [A philosophy kit]. Buenos Aires: Emecé Editores.

WEBSTER'S, N. (1996). New Universal Unabridged Dictionary. Barnes \& Noble Books, New York.

WINNICOTT, D. (1972). Realidad y Juego [Playing and Reality]. Gedisa, Buenos Aires. 